\title{
Rozhovor s Jaroslavem Blechou
}

\author{
Margita Havlíčková
}

PhDr. Jaroslav Blecha (jblecha@mzm.cz) je vedoucí Oddělení dějin divadla v Moravském zemském muzeu v Brně. Oficiální pojmenování jeho funkce na jednom z odborných oddělení MZM však zdaleka nevystihuje rozsáhlé aktivity, které náš host ve svém povolání vykonává. Ani tady je nelze všechny vyjmenovat, ale kdybychom je chtěli opravdu shrnout, dojdeme k překvapujícímu zjištění, že práce muzejníka nespočívá jen v oprašování starých předmětů a lejster uložených v muzeu do skříní a regálů, ale že umí být notně dobrodružná a vzrušující. Že nás dokonce může zavést někam na druhý konec Evropy, kde čekají diváci, kteří mluví kupříkladu dánsky nebo španělsky, a přesto se skvěle baví hrou českých historických pimprlat. Je tomu tak jednoduše proto, že muzejní výstava koncipovaná Jaroslavem Blechou na sebe dokáže vzít, kromě tradičního způsobu prezentace, navíc ještě i podobu živého divadelního představení. Tento specifický přístup k prezentaci muzejních sbírkových předmětů neunikl pozornosti nejen u nás, ale také v zahraničí, když Jaroslav Blecha v roce 2007 obdržel ve španělské Tolose ocenění festivalu Titirijai 07 za přípravu a realizaci dosud nejrozsáhlejší odborné prezentace českého loutkářství v mezinárodním projektu Okno do českého loutkářství.

Jaroslav Blecha je členem významných loutkářských organizací - např. exekutivy Českého střediska UNIMA a také radou mezinárodní UNIMA za Českou republiku. ̌̌ešitelsky se účastnil (a účastní) několika českých i mezinárodních výzkumných projektů a je autorem mnoha odborných studií a několika publikací, mj. Česká loutka (2008), Rodinná loutková divadélka: skromné stánky múz (2009), České rodinné loutkové divadlo (2014), Muzejni maringotka: cesty, křrizovatky, zastaveni (2018). Autorsky se také podílel na dvoudílné publikaci Malované opony divadel českých zemi (2010, 2017).

[MH] Byl nějaký počáteční zážitek, který Tě přivedl k zájmu o divadlo? A kdy to bylo?

[JB] Těch zážitků bylo samozřejmě hodně, ale já jsem je nikdy nevnímal tak, že by mě přímo vedly k divadlu. Spíš jsem to zažíval bezděčně, divadlo se mně líbilo. Když už jsem byl větší, maminka, která pocházela z města a mohla v Brně využít služební byt svého tatínka, mě často brávala do Reduty na operety. V její rodině bylo plno předků, kteří se věnovali muzice. Její pradědeček, dědeček i maminka byli varhaníci a hráli v kostelích na varhany - v Brně a potom v Domašově, kde prarodiče bydleli. Pradědeček, který tam byl řídícím učitelem na venkovské škole, nejenže hrával na varhany o mších, ale přátelil se i s místním farářem, který k nám o poutích chodil do rodiny. To všechno jsem už v té době vnímal jako sofistikované věci. Naopak zase z tatínkovy strany byli rodiče spíš dělnického původu, dědeček byl tesař a truhlář a mě fascinovala práce 
se dřevem. Spíš mě přitahovalo tohle, proto můj první zájem po skončení základní školy bylo studium řezbařiny. Chtěl jsem studovat řezbářství. Jediná možnost byla v Bratislavě, kde tehdy existovala jakási stř̌ední škola, ale tatínek řekl: bohém z tebe nebude. A já jsem zase řekl: tak když nemůžu studovat řezbařinu, tak nebudu studovat nic. Prostě jsem se zatvrdil, šel jsem do učení a vyučil jsem se dřevomodelářem. Prapůvod mé kvalifikace je tedy řemeslo dřevomodelářství. Ale když se vrátím k divadlu, tak těch zážitků jsem měl plno už jako dítě.

Své dětství jsem prožíval na venkově v Javůrku, v malé dědině na hranici Vysočiny dvacet pět kilometrů od Brna. Tam žili rodiče mého tatínka. V sousední vesnici, v Domašově, zase žili rodiče mé maminky, takže jsme to měli dva kilometry od sebe. Já jsem vyrostl v Javưrku, kde jsem taky chodil do školy, do první až páté třídy a v té škole existovalo loutkové divadlo, které bylo docela dobře vybavené. Jistý akademický malîr Tříska jezdil totiž na Javůrek na chalupu a s místním panem řídícím učitelem Hlaváčkem si vymysleli loutkové divadlo. Akademický malír namaloval dekorace, namaloval předlohy loutek a co je zajímavé, loutky vyřezal místní pokrývač, myslím, že se taky jmenoval Hlaváček, ale s panem ředitelem prŕbuzní nebyli. On vyřezal takové docela surově vyhlížející loutky, ale když je pak malî́ Tříska omaloval a ženské z Javưrku ušily kostýmy, získaly jednotný ráz a jsou velmi zajímavé a podmanivé. Dnes je máme tady ve sbírce. Mně se je podařilo získat někdy v osmdesátých letech. To už jsem sice v Javưrku nebydlel, ale přesto jsem zjistil, že se divadlo ve škole zrušilo a přestěhovalo do sokolovny. Jenže když se potom sokolovna rekonstruovala, tak loutky naházeli kamsi do sklepa, ležely tam ve vlhku a poničily se jim kostýmy, poničily se všechny dekorace, ale mně se podařilo domluvit se se starostou, že by nám celé torzo přenechali do muzea.

Takže já jsem jako divák chodil do loutkového divadla už jako malé dítě. Potom o něco později, když jsem byl ve čtvrté nebo v páté třídě, nás pan učitel angažoval jako vodiče loutek. Divadlo fungovalo tak, že se text hry nejdříve nahrál na magnetofonový pásek a zvuk se potom pouštěl ze záznamu. My, starší žáci, jsme dělali vodiče, ale v divadle se angažovali i někteří rodiče. A to už tedy byla moje první praktická zkušenost s loutkami. Taky mě to potom vedlo $\mathrm{k}$ tomu, že jsem si doma sám zkoušel loutky vyřezávat, ačkoliv jsem do té doby neprošel žádným školením. Byly to takové bezděčné, ale přitom velmi intenzivní podněty. Ale nepřemýšlel jsem o tom, že bych mohl divadlo studovat, nebo se jím vůbec nějak zabývat, to rozhodně ne.

\section{[MH] A kdy Tě to tedy napadlo?}

[JB] No, mě to vlastně nikdy nenapadlo. Jak jsem říkal, bylo to tak, že jsem chtěl studovat řezbářství, což mně nebylo umožněno. Tak jsem se vyučil dřevomodelářem, nicméně pak jsem zjistil, že by to znamenalo pracovat celý život někde v továrně bez možnosti nějakého dalšího vývoje, proto jsem se rozhodl, že půjdu studovat střední školu a šel jsem na gymnázium. Současně s gymnáziem jsem chodil na Základní uměleckou školu, protože mě pořád nepřestalo lákat výtvarné umění. Říkal jsem si, že když se potom přece jen budu chtít věnovat řezbařině a když si předtím udělám takovýto základ, tak by to mohlo fungovat. Po gymnáziu jsem zkusil přijímací zkoušky 
na Akademii výtvarných umění v Praze. Tam jsem se ale nedostal, nicméně na základě výsledků těchto zkoušek jsem měl možnost vybrat si jinou školu a já jsem se rozhodl pro divadelní vědu a hudební vědu, což byla kombinace, která se tehdy otvírala v Brně na Filozofické fakultě. Měl jsem takovou bláhovou naivní představu, že bych se tam třeba mohl prakticky věnovat scénografii. To jsem ovšem vủbec netušil, že se jedná o teoreticky zaměřené studium. Teprve až když jsem začal studovat, zjistil jsem, že se tam praktická scénografie nepěstuje.

[MH] Kdo byl tehdy vedoucí divadelní vědy v Brně?

[JB] Vedoucí katedry byl Artur Závodský, který nás učil asi dva roky, načež odešel do důchodu a po něm nastoupil do této funkce Zdeněk Srna. Nejdříve jsem ukončil po čtvrtém ročníku hudební vědu a potom, jako hlavní obor, po pátém ročníku diplomovou prací i divadelní vědu. Preferoval jsem divadelní vědu z důvodu, který jsem zmínil, nicméně v té době jsem už dlouho hrál s hudební skupinou, takže mě zajímala i hudební věda, i když více muzika nonartificiální než vážná. Ale samozřejmě že v rámci studia jsem se věnoval taky hudbě vážné. Když jsem se potom rozhodoval, který z těch oborů bude diplomový, vybral jsem si nakonec divadelní vědu.

\section{[MH] A nelákala Tě brněnská JAMU?}

[JB] Já jsem v té době (rozhodování o vysoké škole) o JAMU ani nevěděl, protože jsem inklinoval spíše k výtvarnému umění. Myslím, že jsem si tehdy procházel nabídky v nějakém bulletinu o vysokoškolském studiu a obor divadelní věda jsem tam našel. V Brně jsem předtím ani nestudoval, sice jsem se tam vyučil, ale gymnázium jsem absolvoval v Ivančicích. Během svých středoškolských studií jsem do Brna jezdil jen málo a o divadlo jsem se nijak výrazněji nezajímal.

[MH] Když už jsi potom studoval na vysoké škole, nepřitahovaly Tě spíše hudební divadelní formy jako opera, opereta, muzikál, jestliže Tě tak intenzivně zajímala hudba a sám jsi ji, byt' $\checkmark$ jiné rovině, aktivně provozoval?

[JB] Samozřejmě, že jsem chodil na operu, operetu i muzikál. My jsme velice často a intenzivně navštěvovali všechna divadla, a to díky profesoru Závodskému, který nám zařídil speciální průkazky, na které jsme jako studenti divadelní vědy mohli chodit do divadel zadarmo. Taky jsme mohli docházet na JAMU na přednášky, například k profesoru Bundálkovi a podobně. Během vysokoškolských studií se náš kontakt se studenty JAMU realizoval i v praktické rovině, protože jsme kamarádili s kolegy z oborů režie, dramaturgie, herectví a jezdili jsme společně na různé festivaly, například do Zlína tehdejšího Gottwaldova atd. 
[MH] To mě těší, že praxe intenzivního kontaktu mezi JAMU a divadelní vědou, kterou zavedl na konci 60. let profesor Bořivoj Srba, pokračovala dál, i když on sám už nesměl učit.

[JB] Profesora Srbu jsem jako pedagoga bohužel už nezažil. Ale v té době na katedře ještě působil filmolog Zdeněk Smejkal, který taky nesměl oficiálně přednášet, nicméně načerno, de facto ilegálně, měl nějaké přednášky o filmu. Ovšem úžasné byly jeho pravidelné pořady, při nichž nám pouštěl filmy, například celý cyklus z Bergmannovy tvorby, samozřejmě s patřičným komentářem a výkladem.

[MH] Chtěla jsem se zeptat, kdy se začínal formovat Tvůj zájem o loutkové divadlo, ale jak slyším, ten Tě provázel od dětství. Navíc zájem o vyřezávání, o práci se dřevem, o jeho umělecké ztvárnění, tak tohle všechno se Ti hodilo, když jsi nastoupil na divadelní oddělení.

[JB] To určitě. Jak už jsem říkal, bylo to zpočátku bezděčné, nebyl tam žádný cílený zájem. Teprve během vysokoškolských studií jsem začal docházet na divadelní oddělení Moravského muzea, kde jsme jako studenti čerpali z různých dokumentačních materiálů, když jsme psali své seminární práce. Kromě toho se nám tam naskytla možnost jakýchsi brigád, sice neplacených, ale zase to bylo pro nás zajímavé, protože jsme si lidově řečeno přičichli k muzejní práci, tj. k dokumentaci divadla. To mě začalo bavit, takže jsem tam chodil pravidelně. A už jsem se taky zúčastnil některých akcí, které na oddělení probíhaly s loutkami - například menší výstavy a podobně. Po letech se mně tam podařilo získat místo - ale to tedy byla kalvárie. Paní doktorka Jiřina Telcová, tehdejší vedoucí a taky zakladatelka divadelního oddělení, při mně sice stála, ale podmínky nebyly vůbec příznivé, prostě nebylo místo. Tehdejší ředitel Moravského muzea Jiří Sejbal mě přesouval, jak to jen šlo. Napřriklad na Městské kulturní středisko, kde jsem vydržel pouhé čtyři dny, protože mě nutili absolvovat kolektivní ranní rozcvičky, což nebylo nic pro mě. Také na Krajský národní výbor, kde jsem měl dělat jakéhosi „kulturtrégra“, tj. administrativní sílu na odboru kultury. Vydržel jsem tam asi měsíc, nebo snad dva. Já jsem ale tvrdohlavě usiloval o práci v muzeu, kterou jsem nakonec přece jen získal, když jsem zde předtím absolvoval řadu brigád jako lektor ve výstavách. Kromě divadelního oddělení např́íklad v expozici národopisu - jako lektor jsem tu četl dětem tematické pohádky, např. v dialektu. Ale nakonec se mně podařilo získat místo na výstavním oddělení, které tehdy vedl doktor Václav Tomášek. Ten sem byl kvůli svému politickému škraloupu také přesunut, a to z Kroměříže, kde dříve působil jako ředitel muzea. Výstavní oddělení bylo jakýmsi naším tandemem, který měl na starosti všechny výstavy realizované v Moravském muzeu. Díky tomu jsem získal poměrně velké a dobré zkušenosti s výstavní činností - s organizováním výstav, s vyplňováním ATA karnetů při cestách do zahraničí, s vývozem sbírkových předmětů a podobně, což se mně potom velice hodilo při práci na divadelním oddělení. Tam se mně posléze podařilo získat místo kurátora a konečně jsem se mohl začít věnovat práci divadelního historika. 
[MH] Výborně! V tomto okamžiku Ti můžu položit otázku, která mě mimořádně zajímá: kdy a jak vznikl při divadelním oddělení soubor Muzejní maringotka?

[JB] To, že se budu věnovat loutkám, jsem samožrejmě netušil. Stalo se to tak, že když z oddělení odešel doktor František Pavlíček, tak nebyl nikdo, kdo by o sbírku loutek odborně pečoval. Vzal jsem si ji proto na starost a začal jsem ji systematicky rozšiřovat. Determinoval jsem řadu věcí, které do té doby nebyly pojmenovány, a podařilo se mně rozšírit ji o tzv. fenomén rodinného loutkového divadla, který tady nebyl zastoupen. Myslím, že se mně za ta léta podařilo sbírku poměrně scelit v tom smyslu, že je v ní zdokumentována kompletní produkce první poloviny 20. století až do konce 50. let, at' už jsou to loutky, nebo stolní loutková divadla a všechno co s tím souvisí. Pochopitelně jsem se také dál zabýval kočovným loutkovým divadlem, takže jsem tuto sbírku, pokud to šlo, rozšiřoval o významné dokumenty, jako je například celá kolekce divadla rodiny Pflegrů, ale i řady dalších rodin loutkářů.

Muzejní maringotka, to je kapitola sama pro sebe. Já jsem shodou okolností v loňském roce vydal knížku, která se věnuje historii tohoto ochotnického souboru. Ten vznikl při divadelním oddělení a jeho počátky se tradují do roku 1970. Tehdy na oddělení ještě nepracoval František Pavlíček, ale Jiří Stejskal, který se potom stal dramaturgem v brněnském studiu České televize. Vedoucí divadelního oddělení byla paní doktorka Jiřina Telcová a jako administrativní pracovnice zde působila Drahomíra Vobejdová. A tehdy také přišla do muzea první kolekce velkých loutek z rodiny Berousků, která původně patřila rodině Flachsů, ale protože se Marie Flachsová přivdala do rodiny Berousků, tak si jako věno přinesla s sebou tuto kolekci velkých loutek. Byl to starý pan Berousek, který je posléze nabídl a prodal muzeu. Loutky oslovily Jiř́ího Jaroše, mimo jiné režiséra loutkového divadla Radost, který spolu s Jiřím Stejskalem vymyslel, že by loutky nemusely být jen expozičním prvkem v muzeu nebo ve výstavách, ale že by mohly také hrát, tj. že by se mohly ukázat publiku ve své původní funkci. Jiří Jaroš proto oslovil Karla Högera, brněnského rodáka, a poprosil ho, zda by zkusil nahrát starou loutkářskou hru. Výběr padl na Dona Šajna. Text této hry byl jakousi koláží z několika dochovaných rukopisů, kterou vytvořil a publikoval Jaroslav Bartoš ve své knize Loutkářské hry českého obrození. Karlu Högerovi se celý nápad zalíbil a tak vznikla úžasná nahrávka, která se hlasovou stylizací vrací k původnímu projevu tradičních kočovných loutkářů, samozřejmě umělecky povýšenému díky profesionálnímu podání Karla Högera. Moravská ústředna v Únanově nám pomohla tím, že vyrobila repliku velkého kočovného divadla, ale při premiéře byly použity originální autentické loutky. Premiéra Dona Šajna se uskutečnila 24. června 1970 na Biskupském dvoře Moravského muzea. Protože inscenace, kterou režíroval Jiří Jaroš, měla velký ohlas, muzejníci se rozhodli, že budou představení reprízovat, ale už ne s originálními loutkami. Nechali si vyrobit v Únanově repliky těchto loutek a s nimi se pak začalo hrát. Soubor se záhy obměnil - začali v něm totiž působit někteří herci z loutkového divadla Radost, a taky dostal své jméno Muzejní maringotka. Dodnes nikdo neví, kdo to jméno vymyslel, ale pravděpodobně to byla doktorka Telcová. Soubor během své existence vystřídal řadu spolupracovníků, svých kamarádů, nadšenců pro divadlo, at̉ už to byli profíci z divadla 
Radost, jako byli Zdeněk Ševčík, Kateřina Rakovčíková, Karel Hegner, Karel Karas, ale zejména Mirko Matoušek, Eva Janěková nebo Vratislav Schilder, kteří těm ostatním, nám amatérům, pomáhali a učili nás, jak zacházet s loutkami a jak s nimi divadlo hrát. Soubor Muzejní maringotka si udržel svoji kontinuitu dodnes. František Pavlíček, který už je sice v důchodu, shromáždil kolem sebe pár mladých nadšenců a znovu obnovil dvě nejstarší inscenace, Dona Šajna a Cirkus, hraný s varietními loutkami.

[MH] Tak tohle jsem netušila a myslela jsem si, že Muzejní maringotka dávno skončila.

[JB] Ano. Původní Muzejní maringotka ve svém velkém složení a velkém rozmachu na nějakou dobu skončila, to je pravda, ale např́klad já a Vratislav Schilder jsme se tomu sporadicky věnovali dál, když jsme z našich loutkových představení udělali doprovod k výstavám. My jsme totiž Muzejní maringotku nevnímali jako divadlo v pravém slova smyslu, ale jako specifickou formu komunikace muzea s návštěvníkem, s divákem. Naše představení se tak staly regulérní součástí výstav. Muzejní expozice ukazovaly nějaký historický materiál a nějaký historický kontext, zatímco představení s loutkami fungovala jako jakási nadstavba, jako specifický druh komunikace s diváky, prostřednictvím které byl tento historický kontext zveřejňován.

V tomto mezidobí, než František Pavlíček znovu obnovil Muzejní maringotku, jsme já a Vratislav Schilder kromě toho několik let pořádali různé workshopy, ale i představení s varietními loutkami a byli jsme i několikrát v Dánsku. Tam jsme vedli specifické semináře a také hráli divadelní představení v rámci různých menších výstav. Takže různé aktivity spojené s Muzejní maringotkou měly svoji kontinuitu nepřerušenou.

[MH] Pokud vím, hráli jste v řadě západních zemí - jak k tomu došlo? Nevzpomínám si, že by ve všech těchto zemích mělo muzeum své výstavy.

[JB] V úplném počátku to bylo spojeno s výstavami. Nejdříve v Polsku - ve Varšavě, v Krakově, v Lodži. Ale potom nás občas pozvali na nějaký festival, aniž bychom tam dělali expozici. Jenže my jsme se i při těchto představeních snažili vystavit alespoň několik exponátů. Proto jsme s sebou vždycky vezli ještě další loutky a z nich jsme udělali miniaturní výstavku, aby publikum mělo informaci o historickém kontextu. To bylo pro nás důležité. Nechtěli jsme totiž působit jako nějaká konzervativní divadelní skupina, která se zabývá něčím, čemu už dnešní divák možná nerozumí. Ale je pravda, že jsme podnikli několik turné, která byla jen divadelní - mimo jiné po Španělsku a Dánsku, kam nás pozvali na festivaly. Jenže ve Španělsku jsou festivaly většinou organizovány tak, že začínají například na severu v Barceloně a potom pokračují dolů na jih do dalších měst, do Segovie, Madridu atd. a skončí až v Seville. Proto se jejich organizátoři snaží navazovat termíny na sebe tak, aby účastníci festivalů, kteří tam účinkují, měli možnost projít, když ne všemi, tak alespoň několika z nich.

To byl tedy příklad turné ze Španělska. V Dánsku, tam jsme zase získali velkou př́ítelkyni, nadšenou pro slovanskou kulturu - když to takto rozšířím - paní Hariett Ludvigsen. Ta nejdříve pracovala na festivalu v Aarhusu, kde jsme se s ní seznámili a kde také 
měla na starosti pobyt celé naší skupiny. Potom, když se přestěhovala na severozápadní pobřeží Dánska do Skjernu a byla tam zaměstnaná v muzeu, nás několikrát pozvala, abychom tam uspořádali výstavu a také nám zorganizovala divadelní turné po Dánsku, at už to byla různá kulturní zařízení nebo školy, případně jiná podobná místa, kde jsme hráli.

[MH] Nemýlím-li se, byli jste taky ve Francii?

[JB] Já osobně jsem s Maringotkou ve Francii nebyl, to bylo ještě na začátku působení Muzejní maringotky. Ve Francii byla Maringotka, tuším, dvakrát - jednou v Pař́̌zi a jednou na festivalu v Charleville-Mézières a tehdy soubor doplnili kromě elektrikáře Jiřího Př́hody a řidiče Vlastimila Petzkeho další lidé z odborných oddělení Moravského zemského muzea. Pokud vím, byli to tehdejší šéf Etnografického ústavu Pavel Kurfürst a také šéf literárního oddělení doktor Jiří Hájek. Teprve později se soubor rozrostl o lidi z loutkového divadla Radost.

Chtěl bych ještě dodat, že knížku, kterou jsem ted’ nedávno vydal, jsem sice nazval $M u$ zejni maringotka: Cesty, krǐžovatky, zastavení, ale nezabývám se tam jenom tímto souborem, i když je tam celá jeho historie a je to doplněno celou řadou fotografií a soupisem všech štací. Nicméně já vnímám Muzejní maringotku jako krédo, jako specifický způsob prezentace muzejního materiálu a komunikace s publikem. Takže jsou tam uvedeny i další akce, jako výstavy a různé workshopy, všechno to, co je jakýmsi rozšířením základní muzejní práce.

[MH] Myslím, že tímto zajímavým způsobem nyní přecházíme k další otázce. Vím, že jako vedoucí Oddělení dějin divadla pokračuješ už řadu let v práci své předchůdkyně, doktorky Jiřiny Telcové. Zajímalo by mě, jak ovlivnila novodobá technika sbírkovou činnost, tj. v čem se liší práce nynějšího kurátora od toho, jak vypadala v 70. letech, to znamená v době, kdy jsi po skončení studia začal pracovat v Moravském zemském muzeu.

[JB] Základ této práce se nezměnil. Prioritou stále je získávání autentických hmotných dokumentů z terénu, což v př́ípadě divadla je, jak víme, problém, protože to zásadní - divadelní artefakt - de facto hmotně neexistuje. Takže my získáváme dokumenty tzv. průvodní. Dalším smyslem muzejní práce je o tyto dokumenty pečovat, ošetřovat je, udržovat je v takovém stavu, abychom je zachovali pro budoucí generace. Ruku $\mathrm{v}$ ruce $\mathrm{s}$ tím potom jde prezentace, abychom je nějakým způsobem přiblížili veřejnosti, at už prostřednictvím odborných publikací a článků, výstavami, přednáškami a tak dále. Samozřejmě se změnil způsob dokumentace a evidence těchto předmětů. Dříve bylo všechno vedeno manuálně, zapisovalo se na tzv. trojdílné karty, psalo se na psacích strojích, vedly se katalogy psané rukou a přírůstkové knihy. Ty se ostatně vedou dodnes. Současně s tím však jde elektronická dokumentace. Na to máme specifický software pro evidenci jednotlivých předmětů, přičemž tato evidence slouží zároveň jako katalog, ve kterém můžeme vyhledávat podle různých filtrů. Je to sice velmi složitá, ale zároveň užitečná věc, protože nabízí různé vazby mezi jednotlivými předměty a to 
nebylo dřive možné, anebo, lépe řečeno, nebylo to tak jednoznačné. Také to umožňuje obrazovou evidenci, což znamená, že řadu předmětů tzv. digitalizujeme, což je dokonce zákonná povinnost daná ministerstvem kultury. V současné době proto digitalizujeme sbírku scénografie a sbírku divadelních cedulí, především těch starších, které se vážou k německojazyčnému divadlu v Brně. Nedávno se nám taky podařilo navázat kontakt s brněnským opatstvím, kde se dochovala obsáhlá kolekce starých cedulí brněnského německého divadla (Brünner Stadttheater) z první poloviny 19. století. Proto jsme s opatstvím uzavřeli smlouvu, na jejímž základě si jednotlivé kusy postupně půjčujeme, skenujeme, digitalizujeme a budou tady $\mathrm{v}$ této podobě $\mathrm{k}$ dispozici pro studenty a badatele. Naše vlastní muzejní sbírka německých cedulí, kterou taky digitalizujeme, je o něco mladší, je až z druhé poloviny 19. a začátku 20. století. Elektronikou jsme vybaveni velmi slušně, a to díky různým grantům, nicméně nám chybí pracovníci - z tohoto hlediska personální stav pracoviště dlouhodobě není dobrý. Já vždycky když píšu nějakou koncepci, nějakou vizi rozvoje pracoviště do budoucna, tak jsem se už mnohokrát snažil povýšit počet odborných pracovníkủ oddělení, nicméně tabulkový systém, který je nám určován naším zřizovatelem, ministerstvem kultury, je tak složitý a striktní, že to nelze udělat. Pro nás je to velký handicap, protože naše síly nekorespondují s tím, co bychom měli a chtěli dělat, což znamená zabývat se divadlem na celé Moravě. Ǩešíme to alespoň provizorně tak, že díky různým grantům získáváme pochopitelně časově omezené smlouvy a dohody např́ílad se studenty. Tak v současné době tady máme tři brigádníky, z nichž dva nám pomáhají evidovat a katalogizovat staré zásoby fotografické sbírky, zatímco jedna paní důchodkyně digitalizuje výstř̌ižky, jako jsou recenze, různé články o divadle atp.

Kromě toho máme v současné době grant NAKI, dotační program ministerstva kultury, který je zaměřen na výzkum a zpracování divadelních cedulí. To je pětiletý projekt, který máme společně s Divadelním ústavem a Národním muzeem v Praze. Ted' jsme ve třetím roce řešení $s$ tím, že letos by měla vzniknout velká výstava v Praze a napřesrok by se měla reprízovat u nás v Brně v Moravském zemském muzeu. Ovšem základem celého projektu jsou dvě položky výzkumného charakteru. Za prvé je to vytvoření databáze výskytu divadelních cedulí v České republice, což je úkol, jehož řešení se týká zejména našeho Oddělení dějin divadla v Moravském zemském muzeu. Tři pracovníci, kteří jsme zde do projektu zapojení, jsme podnikali průzkum různých institucí, muzeí, archivů, ale i soukromých sbírek na Moravě a ve Slezsku a vytvořili jsme databázi, která je v tuto chvíli už téměř zaplněná informacemi. Ty jsme samozřejmě získali nejen my, ale i Národní muzeum a Divadelní ústav. V budoucnu by databáze měla být interaktivní, což znamená dostupná na internetu. $\mathrm{V}$ př́ślušných institucích v různých místech republiky budou také pověření spolupracovníci, jejichž povinností bude informace dál doplňovat a zveřejňovat. Jako další výstupy jsou plánovány i několikeré publikační počiny, ale jedním z hlavních výstupů je vytvoření jakési metodiky zpracování divadelních cedulí, jejich exploatace, tj. způsob, jakým z nich lze těžit podstatné a důležité informace a jakým dalším způsobem potom tyto informace zpracovávat. 
[MH] Moje poslední otázka směřuje k ochotnickému divadlu. Jak je to u vás na oddělení s jeho dokumentací? Zaměřujete se i na ochotníky, nebo vaše pozornost platí výhradně divadlu profesionálnímu?

[JB] Právě v této činnosti nás výrazně omezuje personální stav pracoviště. Jsme zde tři kurátoři, z toho dva jen na částečný úvazek. Na plný úvazek pracuje na oddělení také jedna restaurátorka a kromě toho se mně zatím každoročně daří zajistit jednu kurátorskou sílu, ovšem vždy jen na krátkodobou smlouvu. Při tomto personálním vybavení nezvládneme zabývat se systematicky taky amatérským divadlem. Nicméně máme tu soubory a předměty, které dokumentují i tuto oblast divadla. Konkrétně právě v loutkovém divadle tvořily amatérské produkce první poloviny 20. století celou jednu svébytnou etapu, která potom po druhé světové válce měla nesmírný význam pro utváření profesionálního loutkového divadla. A právě tohle je příklad systematické dokumentace amatérského divadla. Ale jinak se koncentrujeme na profesionální divadlo.

[MH] Přece jen bych se na závěr ráda zeptala ještě na jednu věc. Chystáte v blízké době nějakou větší akci pro veřejnost?

[JB] Je to tak, že jsme společně s Etnografickým ústavem Moravského zemského muzea získali velkou dotaci z evropských fondů na vybudování dlouhodobé expozice v Paláci šlechtičen, která se bude jmenovat Loutkářské uměni a lidová kultura v zrcadle času. O vybudování takové expozice usiluji už 15 let, ale doposud se k tomu nenaskytla příležitost. Proto jsme to suplovali alespoň krátkodobými výstavami, at už loutkářskými nebo jinými - a kdybychom se podívali zpět do historie, tak je to opravdu pěkná řádka akcí. Toto je však př́ležitost, kdy se nám snad přes všechny možné byrokratické překážky, kterých není málo a nejsou jednoduché, podaří expozici vybudovat. Původně se měla otevírat už letos v lednu, ale vzhledem ke komplikacím, o nichž tu mluvím, se nám ji snad podaří realizovat $\mathrm{v}$ příštím roce někdy na podzim.

Nicméně expozice je už ted’ koncipována velkoryse. Mám-li mluvit k její divadelní části, bude zde představeno jak kočovné loutkové divadlo, tak amatérské, zejména rodinné divadlo, a to v plné šíri a v historickém kontextu. Což znamená, že vystavovat budeme nejen loutky, ale celý jev jako takový. Z menších výstav plánovaných v nejbližší době chystáme jednu letos na podzim v prostorách mramorových sálů. Věnována bude devadesátinám významného loutkáře, technologa, řezbáře a sochaře Františka Vítka. Vystavovat budeme nejen jeho loutkářskou tvorbu, ale i sochařskou, kterou v poslední době nikde př́lišs neprezentoval.

[MH] Jak slyším, aktivit máte opravdu hodně. Přeji vám, at’ se vše dobře vydaří, at' nemáte skoro žádné překážky (neodvažuji se říct „žádné překážky”) a už se moc těšíme. Děkuji Ti.

Toto dílo Ize užit v souladu s licenčními podmínkami Creative Commons BY-NC-ND 4.0 International (https://creativecommons.org/ licenses/by-nc-nd/4.0/legalcode). Uvedené se nevztahuje na díla či prvky (např. obrazovou či fotografickou dokumentaci), které jsou v dile užity na základě smluvní licence nebo výjimky či omezení přislušných práv. 
